\title{
Squamous cell carcinoma as a long-term effect after skin vascular malformation radiotherapy
}

\author{
Bartosz Mańkowski ${ }^{1}$, Agnieszka Osmola-Mańkowska², Romuald Olszański ${ }^{3}$, Andrzej Bielecki' ${ }^{1}$ Paweł Grala ${ }^{1}$, \\ Krzysztof Słowiński ${ }^{1}$
}

1Division of Trauma, Burns and Plastic Surgery, Poznan University of Medical Sciences, Poland Head: Prof. Krzysztof Słowiński MD, PhD

2Department of Dermatology, Poznan University of Medical Sciences, Poland

Head: Prof. Wojciech Silny MD, PhD

3Department of Marine and Hyperbaric Medicine, Military Medical Institute, Gdynia, Poland

Head: Prof. Romuald Olszański MD, PhD

Postep Derm Alergol 2012; XXIX, 6: 471-474 DOI: 10.5114/pdia.2012.32397

\begin{abstract}
In the past, vascular anomalies were divided into vascular malformations and vascular tumors. Radiotherapy was one of the leading methods of treatment for vascular malformations and infantile haemangiomas in the past and considered as harmless in those days. Many years later it turned out that management was not necessary and dangerous, even responsible for possible skin cancers appeared within areas exposed to radiotherapy in the future. The case report shows the presence of squamous cell carcinoma within the irradiated vascular malformation of the frontotemporal area in early childhood. The lesion was surgically removed, the defect was covered by split thickness skin graft. The histopathological evaluation confirmed the carcinoma as well as its complete resection. Assessing the adult patients with vascular anomaly one should be aware of possible radiation therapy for that malformation in the past, then the evaluation of the skin must be careful and focused on possible neoplasmatic lesions.
\end{abstract}

Key words: radiotherapy, vascular malformations, squamous cell carcinoma.

\section{Introduction}

In the past vascular anomalies were classified as vascular malformations and vascular tumors such as infantile haemangiomas [1]. This classification was adopted by the International Society for the Study of Vascular Anomaly (ISSVA). The classification is based on the histopathological presentation as well as diagnostic imaging techniques. In the past, Agervall and Kindblom described vascular anomaly as a benign vascular tumor: "broadly defined as a lesion with an increased number of newly formed blood vessels... It is present at birth or it could appear soon after" [2, 3]. The most frequent type of vascular malformations is the stork bite (erythema nuchae) which presents in 40-50\% of all newborns. Vascular anomalies may appear on any part of the body, however, it most often presents on the face, forehead, limbs and chest $[4,5]$. The treatment of this lesion is taken for cosmetic reasons, as well as in the case of the uncontrolled growth risk, bleeding or infection. The large size and volume of the vascular anomalies may cause hemodynamic disturbances leading to a life-threatening condition, although these cases are rare. There were different therapeutic methods proposed in the past, which were more or less aggressive. Resective surgery was performed in the past to remove these lesions but it caused scars and contractures. Usage of injections with sclerosing agents, boiling water, then cryotherapy and compressive therapy were also utilized. Radiotherapy was one of the most common ways to treat vascular anomalies in Europe until the 1960s. In those days this approach to the vascular anomalies seemed to be harmless and generally accepted as a non-invasive treatment causing no scaring [2, 6, 7]. It was advocated to initiate the therapy as early as possible to stop the evolution of this lesion because it was believed that vascular anomalies in younger children is much sensitive to radiotherapy. These suggestions had no reflection in the literature and the doses of the radiation varied in different health centers in that era [2]. Some countries recognized that method as a first choice treatment in the case of vas-

Address for correspondence: Agnieszka Osmola-Mańkowska MD, PhD, Department of Dermatology, Poznan University of Medical Sciences, 49 Przybyszewskiego St, 60-355 Poznan, Poland, phone: +48 795418 182, e-mail: agnieszka.osmola@wp.pl 
cular malformations and haemangiomas even up until the 1970s. Today we have a lot of evidence of the carcinogenic effect of radiation, which is well-documented in the epidemiological studies [7, 8]. Radio-induced malignancies of the skin occur many years after completing the radiation therapy applied for other medical conditions such as hemangioma and they include squamous cell carcinoma [9], basal cell carcinoma [10-12], Merkel cell carcinoma [13], angiosarcoma [14], leiomyosarcoma [15], sebaceous cell carcinoma [16], soft tissue sarcoma [17] and melanoma [7].

\section{Case report}

A 48-year-old male patient presented with skin lesion located on residual vascular malformation of the right frontotemporal area (Figure 1). The surgical treatment was performed at the Division of Trauma, Burns and Plastic Surgery, Poznan University of Medical Sciences in 2007. The patient complained of discomfort in that place. He noticed the lesion 6 months ago. Suspected skin lesion was located in the center of the vascular malformation. It presented as a solid nodule $2.5 \mathrm{~cm} \times 2 \mathrm{~cm}$ in size, pale pink

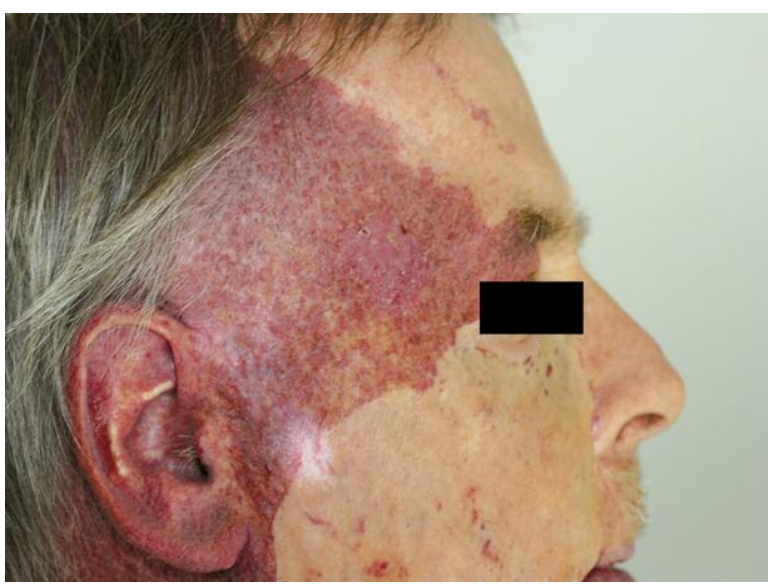

Figure 1. Residual vascuar malformation of the right frontotemporal area with a skin lesion in the middle of it

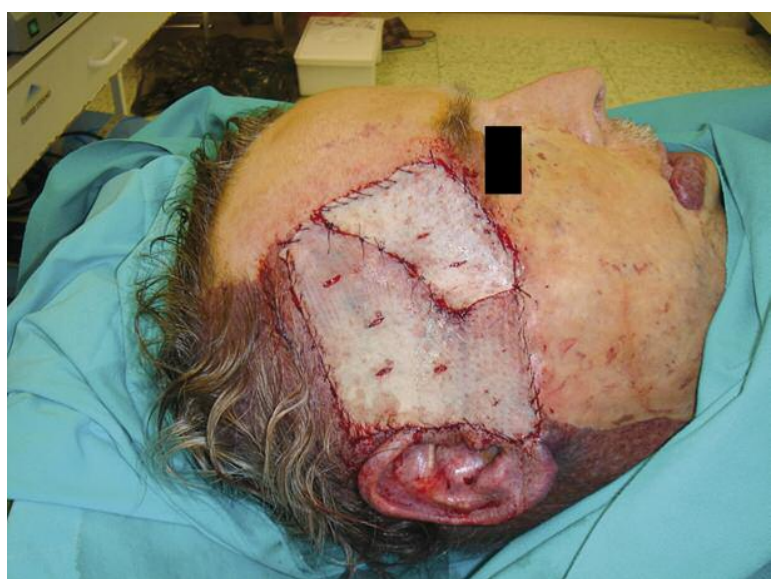

Figure 3. Split thickness skin graft applied onto the wound of the frontotemporal area color with irregular surface with two small ulcerations on the upper part of the lesion. The patient has had vascular malformation present on his face, neck and upper chest, both hands and right thigh. As a child when he was 4 years old, he underwent a course of radiotherapy to reduce the size of vascular malformation. No information regarding the dose of the radiation applied was available. A slight involution of the vascular malformation was seen after radiotherapy. As an adult, he underwent two surgical procedures to have the vascular malformation excised. The malformation was removed, then the split thickness skin graft was applied on the right part of the face, then the second operation on the left side of the face was performed. The current treatment was similar. The whole skin with vascular malformation and the lesion of the frontotemporal right area was removed, then the entire fragment of the skin was sent for the histopathological evaluation (Figure 2). The partial thickness skin graft was harvested from the right buttock using the drum dermatome. The skin graft was applied to the wound and sutured (Figure 3). The skin graft healed perfectly with no complications (Figure 4). The squamous cell carcinoma was diagnosed in the histopathological

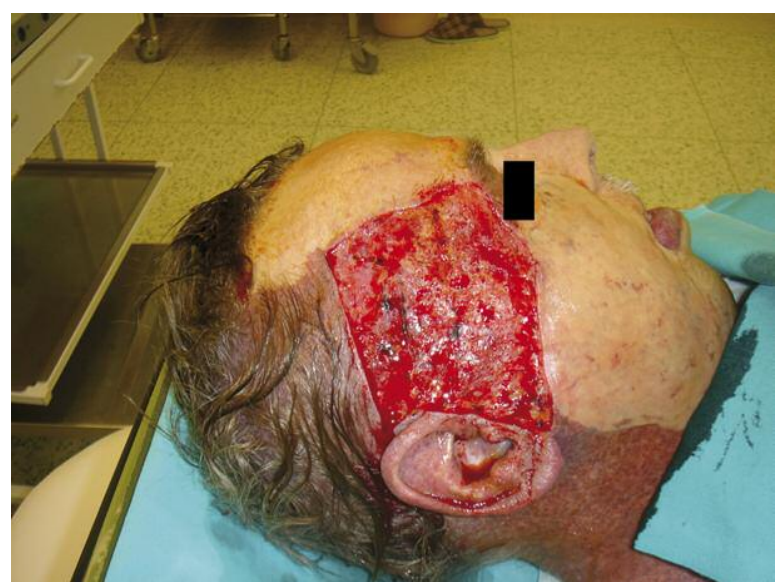

Figure 2. Patient after the excision if the vascular malformation of the frontotemporal area

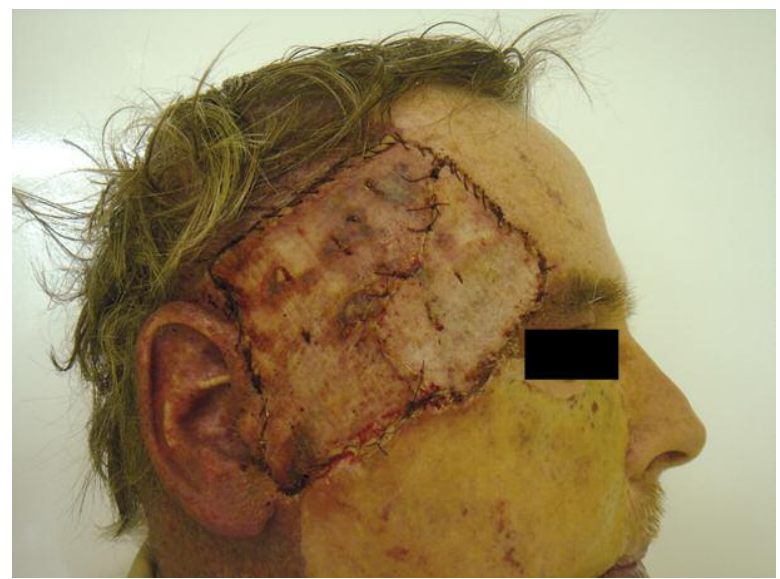

Figure 4. The outcome 2 weeks after the surgery 
specimen. The excision of the carcinoma was complete. The patient was satisfied with the outcome of the surgical treatment.

\section{Discussion}

The radiotherapy is one of the most important treatment methods in modern oncology and dermatology [18-20]. It is a treatment of choice or it supports other means of therapy for a variety of malignant tumors. In the beginning of the radiotherapy era this way of treatment became the main method of treatment for vascular anomalies and continued up to the 1970s [21-23]. It was believed that radiotherapy was harmless and favorable as compared to aggressive surgical procedures. Many authors suggested starting the radiotherapy for vascular malformations and haemangiomas in younger children to achieve the best regression. Several authors compared radiotherapy of haemangiomas with untreated cases. It appeared that patients who received no therapy had their lesions involuted even better than the treated cases [24-27]. After these findings, radiotherapy for haemangiomas was ceased. From that point no treatment and only careful observation was undertaken leaving the surgery as a last treatment method in cases with unsatisfied spontaneous hemangioma regression [24]. Léauté-Labréze et al. reported promising outcomes of hemangioma treatment with systemic propranolol as well as recently with topical propranolol ointment, it seems to be safer than steroid therapy in the case of severe hemangioma [28, 29]. These days the first line treatment of vascular malformations is laser therapy instead of radiotherapy. Today patients come back with neoplasmatic lesions located in previously irradiated areas. The term radio-induced malignancy is used in the case of history for previous irradiation, cancer present in the irradiated area, tissue injury due to a high dose of radiation therapy, and when the time between radiotherapy and the neoplasm occurrence is [3] from 2 to 47 years [30-32]. Heikens et al. suggested that the risk of cancer is greater in a patient exposed to radiotherapy in childhood [33]. Some authors report squamous cell carcinoma (SCC) as a late complication after radiotherapy for hemangioma [23], moreover, some patients developed radiodermatitis with SCC [34]. There were cases of malignant melanoma in previously irradiated areas, these situations were rare but it seems that other factors may increase the risk of neoplasmatic transformation such as smoking cigarettes, chemotherapy, age at exposure [35, 36]. Basal cell carcinoma may develop after radiotherapy for a port wine stain rather than after other methods of treatment such as argon or pulsed dye laser therapy [37].

There are other serious consequences of radiotherapy applied for vascular anomalies apart from skin cancer. The mammary gland is sensitive to radiation-associated carcinogens particularly in patients who were exposed to radiation in childhood [38]. The breast cancer risk occurs even thirty years after irradiation [39] and Lundell et al. expands the estimated risk up to 50 years [40]. Malignances after radiotherapy were found in the central nervous system, thyroid and other endocrine glands [41-43]. There was assessed progeny of irradiated women in their young age and the significant higher numbers of neural tube defects were observed [44]. Nowadays in the era of lasers, radiotherapy for hemangioma was abandoned, however, some authors appreciate this method in life- or function-threatening hemangiomas [45].

Basal and squamous cell carcinoma as an effect of radiation therapy for vascular anomalies may reveal an atypical clinical appearance, become difficult to diagnose or to be misdiagnosed. One should pay special attention in reviewing adult patients with vascular anomalies, especially in the case of additional skin changes with a past history of radiation therapy. Careful examination is recommended in these cases not to bypass possible radio-induced lesions [36]. The increased cancer-related mortality was observed in patients who underwent radiotherapy for skin vascular anomalies and they should be followed up later on [6].

\section{References}

1. Mulliken JB, Glowacki J. Hemangiomas and vascular malformations in infants and children: a classification based on endothelial characteristics. Plast Reconstructr Surg 1982; 69: 412-22.

2. Lindberg S. Radiotherapy of childhood haemangiomas: from active treatment to radiation risk estimates. Radiat Environ Biophys 2001; 40: 179-89.

3. Angervall L, Kindblom LG. Tumors and tumorlike lesions of blood vessels. In: Contemporary issues in surgical pathology. Ninfo V, Chung EB, Cavazzano AO (eds). Churchill Livingstone 1999; 123-4.

4. Li DN, Gold MH, Sun ZS, et al. Treatment of infantile hemangioma with optimal pulse technology. J Cosmet Laser Ther 2010; 12: 145-50.

5. Poetke M, Philipp C, Berlien HP. Flashlamp-pumped pulsed dye laser for hemangiomas in infancy: treatment of superficial vs mixed hemangiomas. Arch Dermatol 2000; 136: 628-32.

6. Dondon MG, de Vathaire F, Shamsaldin A, et al. Cancer mortality after radiotherapy for a skin hemangioma during childhood. Radiother Oncol 2004; 72: 87-93.

7. Trefzer U, Voit C, Milling A, et al. Malignant melanoma arising in a radiotherapy field: report of two cases and review of the literature. Dermatology 2003; 206: 265-8.

8. Ron E. Ionizing radiation and cancer risk: evidence from epidemiology. Radiat Res 1998; 150: 30-41.

9. Frieben A. Cancroid nach langdauernder Einwirkung von Röntgenstrahlen. Fortschr Geb Röntgenstrahlen 1907; 6: 106-8.

10. Iwamoto I, Endo M, Kakinuma $\mathrm{H}$, et al. Multiple basal cell carcinoma developing two years after 60Co irradiation. Eur J Dermatol 1998; 8: 180-2.

11. Grammer-West NY, Fitzpatrick JE, Eng TY. Mantle radiation induced symmetrical basal cell carcinomas over the acromioclavicular joints. Dermatol Surg 1996; 22: 481-2.

12. Copas P, Spann CO, Majmudar B, et al. Basal cell carcinoma due to radiotherapy for carcinoma of the cervix. South Med J 1995; 88: 1161-2. 
13. Onodera K, Ichinohasama R, Ooya K. Double malignant neoplasms occurring long after local radiation to the oral mucosa. Virchows Arch 1998; 433: 391-4.

14. Krasagakis K, Hettmannsperger U, Tebbe B, et al. Cutaneous metastatic angiosarcoma with a lethal outcome, following radiotherapy for a cervical carcinoma. Br J Dermatol 1995; 133: 610-4.

15. Aoki T, Ozeki Y, Watanabe M, et al. Development of primary leiomyosarcoma of the sternum postirradiation. Surg Today 1998; 28: 1326-32.

16. Rumelt S, Hogan NR, Rubin PA, et al. Four-eyelid sebaceous cell carcinoma following irradiation. Arch Ophthalmol 1998; 116: 1670-2.

17. Chapelier AR, Bacha EA, de Montpreville VT, et al. Radical resection of radiation-induced sarcoma of the chest wall: report of 15 cases. Ann Thorac Surg 1997; 63: 214-9.

18. Narbutt J, Lesiak A, Arkuszewska C, et al. The usefulness of radiotherapy in treatment of benign familial pemphigus. Post Dermatol Alergol 2006; 23: 111-5.

19. Broniarczyk-Dyła G, Wawrzycka-Kaflik A, Urysiak I. Keloids and hypertrophic scars. Post Dermatol Alergol 2006; 23: 234-8.

20. Batycka-Baran A, Reich A, Jankowska-Konsur A, et al. New trends in the management of mycosis fungoides and Sezary syndrome. Post Dermatol Alergol 2009; 26: 41-55.

21. Forssell G. Röntgenoch radiumbehandlingen vid kirurgiska sjukdomar. In: Nordiskt Lärobok i Kirurgi I. Munksgaard, Köpenhamn 1940; 549.

22. Andrén $\mathrm{G}$. The radium treatment of haemangiomata, lymphangiomata and naevi pigmentosi. Experiences from 'Radiumhemmet', 1909-1924. Acta Radiol 1927; 8: 1-45.

23. Erfurt-Berge C, Bauerschmitz J. Squamous cell carcinoma as a long-term effect of Tantalum-182 irradiation in childhood. Eur J Dermatol 2010; 20: 843-4.

24. Blackfield HM, Torrey FA, Morris WJ, et al. The management of hemangiomata; a plea for conservatism ininfancy. Plast Reconstr Surg 1957; 20: 38-44.

25. Blackfield HM, Torrey FA, Morris WJ, et al. The management of visible hemangiomas. Am J Surg 1957; 94: 313-20.

26. Blackfield HM, Torrey FA, Morris WJ, et al. The conservative treatment of hemangiomas in infants and children. J Int Coll Surg 1958; 30: 255-61.

27. Blackfield HM, Morris WJ, Torrey FA. Visible heman-giomas. A preliminary statistical report of a 10-year study. Plast Reconstr Surg 1960; 26: 326-9.

28. Léauté-Labréze C, Dumas de la Roque E, Hubiche T, et al. Propranolol for severe hemangiomas of infancy. N Engl J Med 2008; 358: 2649-51.

29. Kunzi-Rapp K. Topical propranolol therapy for infantile hemangiomas. Pediatr Dermatol 2012; 29: 154-9.

30. Fishman SJ, Mulliken JB. Hemangiomas and vascular malformations of infancy and childhood. Pediatr Clin North Am 1993; 40: 1177-200.

31. Burton-Esterly N. Cutaneous hemangiomas, vascular stains, and associated syndromes. Curr Probl Pediatr 1987; 17: 1-69.

32. Mulliken JB. Cutaneous vascular anomalies. Semin Vasc Surg 1993; 6: 204-18.

33. Heikens J, Somers R, Behrendt H, et al. Late sequelae of oncologic treatment in children. Ned Tijdschr Geneeskd 1998; 142: 2191-25.

34. Peter RU, Gottlober P, Nadeshina N, et al. Radiation lentigo: a distinct cutaneous lesion after accidental radia tion exposure. Arch Dermatol 1997; 133: 209-11.

35. Ron E, Preston DL, Kishikawa M, et al. Skin tumor risk among atomic-bomb survivors in Japan. Cancer Causes Control 1998; 9: 393-401.
36. Haddy N, Mousannif A, Paoletti C, et al. Radiotherapy as a risk factor for malignant melanoma after childhood skin hemangioma. Melanoma Res 2012; 22: 77-85.

37. Jasim ZF, Woo WK, Walsh MY, et al. Multifocal basal cell carcinoma developing in a facial port wine stain treated with argon and pulsed dye laser: a possible role for previous radiotherapy. Dermatol Surg 2004; 30: 1155-7.

38. Haddy N, Dondon MG, Paoletti C, et al. Breast cancer following radiotherapy for a hemangioma during childhood. Cancer Causes Control 2010; 21: 1807-16.

39. Hildreth NG, Shore RE, Dvoretsky PM. The risk of breast cancer after irradiation of the thymus in infancy. N Engl J Med 1989; 321: 1281-4.

40. Lundell M, Mattsson A, Hakulinen T, et al. Breast cancer after radiotherapy for skin hemangioma in infancy. Radiat Res 1996; 145: 225-30.

41. Lindberg S, Karlsson P, Arvidsson B, et al. Cancer incidence after radiotherapy for skin haemangioma during infancy. Acta Oncol 1995; 34: 735-40.

42. Biaoxue R, Shuanying Y, Xiguang C, et al. Differential diagnostic CYFRA 21-1 level for benign and malignant pleural effusions: a meta-analysis in the Chinese population. Arch Med Sci 2012; 8: 756-66.

43. Galbiatti AL, Ruiz MT, Raposo LS, et al. The association between CBS844ins68 polymorphism and head and neck squamous cell carcinoma risk - a case-control analysis. Arch Med Sci 2010; 6: 772-9.

44. Källén B, Karlsson $P$, Lundell M, et al. Outcome of reproduction in women irradiated for skin hemangioma in infancy. Radiat Res 1998; 149: 202-8.

45. Ogino I, Torikai K, Kobayasi S, et al. Radiation therapy for lifeor function-threatening infant hemangioma. Radiology 2001; 218: 834-9. 